\title{
CONTROL OF Colletotrichum gloeosporioides (penz.) Sacc. IN YELLOW PASSION FRUIT USING Cymbopogon citratus
} ESSENTIAL OIL

\author{
Nina Duarte Anaruma ${ }^{1}$, Flávio Luís Schmidt ${ }^{1}$, Marta Cristina Teixeira Duarte ${ }^{* 2}$, Glyn Mara Figueira ${ }^{2}$, Camila \\ Delarmelina $^{2}$, Eliane Aparecida Benato ${ }^{3}$, Adilson Sartoratto ${ }^{2}$
}

\author{
${ }^{1}$ Departamento de Tecnologia de Alimentos, Faculdade de Engenharia de Alimentos, Universidade Estadual de Campinas, \\ Campinas, SP, Brasil; ${ }^{2}$ Centro Pluridisciplinar de Pesquisas Químicas, Biológicas e Agrícolas, Universidade Estadual de \\ Campinas, Campinas SP, Brasil; ${ }^{3}$ Instituto de Tecnologia de Alimentos, Campinas, SP, Brasil.
}

Submitted: August 18, 2008; Returned to authors for corrections: March 30, 2009; Approved: September $28,2009$.

\begin{abstract}
The use of antibiotics in agriculture is limited when compared to their applications in human and veterinary medicine. On the other hand, the use of antimicrobials in agriculture contributes to the drug resistance of human pathogens and has stimulated the search for new antibiotics from natural products. Essential oils have been shown to exert several biological activities including antibacterial and antifungal actions. The aim of this study was to determine the activity of 28 essential oils from medicinal plants cultivated at CPMA (Medicinal and Aromatic Plants Collection), CPQBA/UNICAMP, against Colletotrichum gloeosporioides (Penz.) Sacc., the anthracnose agent in yellow passion fruit (Passiflora edulis Sims f. flavicarpa Deg), as well as evaluating their effect in the control of post-harvest decay. The oils were obtained by water-distillation using a Clevenger-type system and their minimal inhibitory concentrations (MIC) determined by the micro-dilution method. According to the results, 15 of the 28 essential oils presented activity against Colletotrichum gloeosporioides, and the following four oils presented MIC values between 0.25 and $0.3 \mathrm{mg} / \mathrm{mL}$ : Coriandrum sativum, Cymbopogon citratus, Cymbopogon flexuosus and Lippia alba. The evaluation of Cymbopogon citratus essential oil in the control of post-harvest decay in yellow passion fruit showed that the disease index of the samples treated with the essential oil did not differ $(P \leq 0.05)$ from that of the samples treated with fungicide. The present study shows the potential of Cymbopogon citratus essential oil in the control of the anthracnose agent in yellow passion fruit.
\end{abstract}

Key words: yellow passion fruit; Colletotrichum gloeosporioides; anthracnose; antimicrobial activity; minimal inhibitory concentration.

*Corresponding Author. Mailing address: Centro Pluridisciplinar de Pesquisas Químicas, Biológicas e Agrícolas - CPQBA - C.P. 6171 - Universidade Estadual de Campinas (UNICAMP), 13083-970, Campinas SP, Brasil.; Tel: 551938847500 Fax: 55 19 3884 7811.; E-mail: mduarte@cpqba.unicamp.br 


\section{INTRODUCTION}

After the introduction of antibiotics in the fight against bacterial diseases about six decades ago, phytopathologists quickly recognized the potential of using antibiotics against plant diseases, especially against those caused by bacteria (14). During the 1950s, about 40 drugs from bacterial and fungal origins were tested to control phytopathologies (10), the primary targets of the antibiotics being some bacterial diseases in vegetables and apple and pear rust.

Nowadays, the use of antibiotics in agriculture is limited when compared to their medicinal and veterinary applications (14). According to Iacobells et al. (11), the control of plant diseases is difficult due to the limited availability of bactericides, and also, with the emergency of antibioticresistant bacterial strains, the control of phytopathologies has become further limited. The question of whether their use in agriculture contributes to the development of antibiotic resistant human pathogens has also been the subject of discussion in recent years in both Europe and North America.

This fact has stimulated the search for natural products with antimicrobial activity, and new strategies for this type of search, including the effective screening of natural products, should lead to the development of new antifungal drugs (12).

With respect to essential oils, many have shown good potential in the control of bacterial diseases, particularly in the eradication of those present in seeds (5), but studies on the use of essential oils as antimicrobial agents are limited (11). The pioneer research of Maruzzella et al. (13) was followed by a few studies on the action of essential oils in the control of phytophatogens (11).

Recently some studies have demonstrated the in vitro efficiency of essential oils and their extracts against important phytopathogenic microorganisms, such as Allium sativum extract, tested against 10 bacteria including Agrobacterium tumefaciens, Erwinia carotovora, Pseudomonas syringae and Xanthomonas campestris (6).

Yellow passion fruit (Passiflora edulis Sims f. flavicarpa) has achieved a space on the juice and juice products market, due to its exotic taste, strong tropical aroma, high acidity and pulp yield (9). This plant is from tropical America and belongs to the Passifloriaceae family, which contains more than 200 native species in Brazil. Despite its commercial importance, yellow passion fruit presents significant losses due to withering and decay, and the main pathogens responsible are the fungi Colletotrichum, Rhizopus, Cladosporium, Fusarium, Lasiodiplodia \& Phomopsis, Alternaria alternata, A. passiflorae, Septoria passiflorae and Sclerotinia sclerotium (3, 4, 19).

Colletotrichum gloeosporioides is responsible for anthracnose in yellow passion fruit and attacks the fruit before and post-harvest. Several chemical methods are used to control the disease, but increasing restrictions regarding the use of fungicides due to food and environmental safety, have stimulated the use of natural and biological methods. Thus, the aim of this study was to determine the in vitro activity of essential oils against $C$. gloeosporioides, and to evaluate its effects in the control of post-harvest diseases in yellow passion fruit.

\section{MATERIAL AND METHODS}

\section{Microorganism}

Colletotrichum gloeosporioides CBMAI 869 was isolated from infected fruits and identified by Dra. Eliane Aparecida Benato - Instituto de Tecnologia de Alimentos (ITAL) Campinas, SP, Brazil. The culture was maintained on PDA (potato dextrose agar) and sub-cultured periodically with alternating light $(12 \mathrm{~h}$ light/ $12 \mathrm{~h}$ dark) during 7 days. The culture was deposited at CBMAI - Brazilian Collection of Microorganisms from Environment and Industry.

\section{Plant Material}

A list of the plants studied, including the botanical name and voucher specimen, are listed in Table 1. The plants were cultured at CPMA - Medicinal and Aromatic Plants Collection of the Chemical, Biological and Agricultural Research Center (CPQBA), State University of Campinas - São Paulo - Brazil. 
The plants were collected from November 2001 to February 2003, always in the morning after dewpoint. The maximum and minimal temperatures registered in the period were $32.2{ }^{\circ} \mathrm{C}$ and $17.3{ }^{\circ} \mathrm{C}$, respectively with precipitation of about $1.777 \mathrm{~mm}$. Voucher specimens were deposited at the State University of Campinas Herbarium (UEC) and identified by Dr. Washington Marcondes Ferreira Neto (curator) or at the CPQBA herbarium.

Table 1. Medicinal plants, voucher specimens, oil yields and antimicrobial activity (MIC) against C. gloeosporioides.

\begin{tabular}{|c|c|c|c|c|}
\hline Medicinal species & Family & Voucher & $\begin{array}{c}\text { Oil yield } \\
(\%)\end{array}$ & $\begin{array}{c}\text { MIC } \\
\text { mg mL }^{-1} \\
\end{array}$ \\
\hline Achillea colina $\mathrm{L}$ & Asteraceae & CPMA 373 & 0.27 & $*$ \\
\hline Allium tuberosum & Liliaceae & CPMA 653 & 0.0011 & 2.0 \\
\hline Aloysia gratissima (Gill \& Hook) & Verbenaceae & UEC 121.393 & 1.51 & $*$ \\
\hline Anthemis nobilis & Asteraceae & UEC 121.411 & 0.05 & 2.0 \\
\hline Artemisia annua & Asteraceae & CPMA 1246 & 0.35 & $*$ \\
\hline Baccharis dracunculifolia & Asteraceae & CPMA 622 & 0.30 & 2.0 \\
\hline Baccharis trimera (Less.) Dc. & Asteraceae & CPMA 1 & 0.30 & $*$ \\
\hline Cordia verbenaceae (Jacq.) Roem. \& & Boraginaceae & UEC 112.744 & 0.04 & 2.0 \\
\hline Coriandrum sativum & Apiaceae & CPMA 664 & 0.08 & 0.25 \\
\hline Cymbopogon citratus & Poaceae & UEC 127.112 & 0.40 & 0.25 \\
\hline Cymbopogon flexuosus & Poaceae & UEC 127.113 & 0.20 & 0.25 \\
\hline Cymbopogum martinii Motia. & Poaceae & UEC 127.115 & 1.36 & 0.70 \\
\hline Cymbopogum winterianus $\mathrm{L}$. & Poaceae & UEC 121.414 & 1.88 & $*$ \\
\hline Cyperus articulatus & Cyperaceae & UEC 121.396 & 6.70 & $*$ \\
\hline Cyperus rotundus & Cyperaceae & CPMA 1252 & 0.03 & $*$ \\
\hline Lippia alba (Mill) N.E. Br. & Verbenaceae & UEC 121.413 & 1.10 & 0.3 \\
\hline Mentha piperita $\mathrm{L}$. & Lamiaceae & UEC 127.110 & 1.20 & 2.0 \\
\hline Mikania glomerata Sprengel. & Asteraceae & UEC 102.047 & 0.06 & $*$ \\
\hline Ocimum gratissimum $\mathrm{L}$. & Lamiaceae & UEC 121.407 & 0.74 & 2.0 \\
\hline Ocimum selloii Benth. & Lamiaceae & UEC 121.406 & 0.18 & $*$ \\
\hline Origanum applii (Domin) Boros & Lamiaceae & UEC 121.410 & 0.20 & 1.0 \\
\hline Origanum vulgare L. Ssp Virens & Lamiaceae & UEC 121.409 & 0.12 & 1.0 \\
\hline Piper aduncum L. & Piperaceae & UEC 127.118 & 0.60 & 2.0 \\
\hline Rosmarinus officinalis $\mathrm{L}$ & Lamiaceae & CPMA 1792 & 1.85 & $*$ \\
\hline Santolina chamaecyparissus $\mathrm{L}$ & Asteraceae & CPMA 1653 & 0.15 & $*$ \\
\hline Stachys byzantina C.Koch. & Lamiaceae & UEC 121.404 & 0.44 & $*$ \\
\hline Stachytarphetta cayenensis (L.C. & Verbenaceae & UEC 121.394 & 0.04 & $*$ \\
\hline Thymus vulgaris L. & Lamiaceae & UEC 121.405 & 0.56 & 2.0 \\
\hline
\end{tabular}

\section{Essential oil extraction \& GC and GC-MS analyses of the essential oils}

The essential oils were obtained from $40 \mathrm{~g}$ of the aerial parts of fresh plants by hydrodistillation for $3 \mathrm{~h}$ using a Clevenger-type system. The aqueous phase was extracted three times with $50 \mathrm{~mL}$ dichloromethane. The pooled organic phases were dried with sodium sulfate, filtered and the solvent evaporated to dryness. The oil samples were stored at $-70{ }^{\circ} \mathrm{C}$ in sealed glass vials.
Identification of the volatile constituents was performed using a Hewlett-Packard 5890 Series II gas chromatograph, equipped with a HP-5971 mass selective detector and HP-5 capillary column ( $25 \mathrm{~m} \times 0.2 \mathrm{~mm} \times 0.33 \mu \mathrm{m}$ diameter). GC and GC-MS were performed using split/splitless injection, with the injector set at $220{ }^{\circ} \mathrm{C}$ and the column initially at $60{ }^{\circ} \mathrm{C}$, with a heating ramp of $3{ }^{\circ} \mathrm{C} \cdot \mathrm{min}^{-1}$ to a final temperature of $240{ }^{\circ} \mathrm{C}$, maintained for a further $7 \mathrm{~min}$. The FID detector was set at 250 ${ }^{\circ} \mathrm{C}$. Helium was used as the carrier gas at $1 \mathrm{~mL} \mathrm{~min}^{-1}$. The GC- 
MS electron ionization system was set at $70 \mathrm{eV}$. A sample of the essential oil was dissolved in ethyl acetate for the analyses. The retention indices (RI) were determined by co-injection of hydrocarbon standards. The oil components were identified by comparison with data from the literature (1), the profiles from the Wiley 138 and Nis 98 libraries, by co-injection of authentic standards, when available.

\section{Inoculum for the antimicrobial assay (16)}

In order to induce conidia and spore formation, $C$. gloeosporioides was cultured in Petri dishes as indicated above. The culture surfaces were then washed with $1 \mathrm{~mL}$ $0.85 \%$ sterile saline solution and $0.01 \mathrm{~mL}$ Tween 20. The resulting mixture of conidia and mycelia fragments was transferred to a sterile tube and after 3-5 min the upper layer suspension was transferred to another sterile tube and submitted to vortex agitation for $15 \mathrm{sec}$. The density of the suspension was adjusted to between OD 0.09 and 0.11 in a spectrophotometer (Shimadzu UV mini1240) and then diluted 1:50 in RPMI-1640 medium.

\section{Antimicrobial assay - minimal inhibitory concentration (MIC) Test}

The assays were carried out according to NCCLS (16) using a tissue culture test plate (96 wells) and RPMI-1640 medium. The stock oil solutions were diluted and transferred into the first well, and serial dilutions made to obtain concentrations in the range from 2.0 to $0.0019 \mathrm{mg} \mathrm{mL}^{-1}$. Amphotericin B (Merck) was used as the reference antimycotic control at $60.0-5.0 \mu \mathrm{g} \mathrm{mL}^{-1}$. The spore solution was added to all the wells and the plates incubated at $35{ }^{\circ} \mathrm{C}$ for $48 \mathrm{~h}$. The MIC was defined as the lowest oil concentration that inhibited visible growth, as indicated by a change in color of the medium (pink to yellow).

\section{Effect of Cymbopogon citratus essential oil on the control of diseases in yellow passion fruit}

The evaluation of disease control efficiency was carried out according to Benato et al. (3). The fruits cv. Afruvec with $1 / 3$ of the peel yellow, were submitted to treatment with $C$. citratus oil at the previously determined MIC concentration. Water and Sportak® (prochloraz), a control fungicide, were used as the standard treatment. A total of 7 treatments with 3 replicates of 10 fruits each were employed. The fruits were submerged for $2 \mathrm{~min}$ in $5 \mathrm{~L}$ of the following solutions: 1. water; 2. Sportak ${ }^{\circledR}, 0.5 \mathrm{~mL} \mathrm{~L}^{-1}$ (a.i.); 3. essential oil, $0.12 \mathrm{~g} \mathrm{~L}^{-1}$; 4. essential oil, $0.25 \mathrm{~g} \mathrm{~L}^{-1}$; 5. essential oil, $0.5 \mathrm{~g} \mathrm{~L}^{-1}$; 6. essential oil, $1.0 \mathrm{~g} \mathrm{~L}^{-1} ; 7$. The concentration of the original essential oil was $2.0 \mathrm{~g} \mathrm{~L}^{-1}$. For treatments 2-7, an adhesive emulsifier (Agral®) was added at $0.3 \mathrm{~mL} \mathrm{~L}^{-1}$. All the fruits were numbered for identification during the subsequent evaluation. After the applications, the fruits were stored at $23-25{ }^{\circ} \mathrm{C}$ and $75-85 \%$ relative humidity for 7 days.

\section{Disease evaluation}

The incidence and infection severity for each fruit on the second, fifth and seventh days after application were evaluated on a scale from 0 to 4 , where: $0=$ absence of symptoms; $1=\leq$ $25 \%$ infected area; $2=26 \leq 50 \% ; 3=51 \leq 75 \%$ and $4=76 \leq$ $100 \%$. The results were expressed on a disease index scale according to the formula I.D. $(\%)=\left\{\left[\left(1 \cdot n_{1}\right)+\left(2 \cdot n_{2}\right)+\left(3 \cdot n_{3}\right)+\right.\right.$ $\left.\left.\left(4 . \mathrm{n}_{4}\right)\right] .(\mathrm{R} .4)^{-1}\right\} .100$, where I.D. $=$ the disease index $(\%) ; \mathrm{n} 1_{\ldots 4}=$ number of fruits with respective score; $\mathrm{R}=$ number of fruits per treatment.

The means obtained for the different treatments were submitted to an analysis of variance and compared by Tukey at $5 \%$ significance. For the statistical analyses the means were transformed by $\sqrt{x+0.5}$.

\section{Physicochemical analyses}

The following analyses were realized at the beginning $(0-$ treatment zero) and on the eighth day, using 8 fruits from each treatment:

Peel color: The peel color was measured 4 times for each fruit using a Minolta (CR300) Colorimeter - System L*a*b*, subsequently calculating the mean value for each fruit.

Soluble solids: The soluble solids contents of the juice from each fruit were determined in a manual refractometer (Atago, 0-32 ${ }^{\circ}$ Brix). 
Titratable acidity and pH: The acidity and $\mathrm{pH}$ of the juice were measured using a pH- meter (Mettler Toledo 320). The results were expressed in g citric acid / $100 \mathrm{~g}$ juice. The acidity was determined using the formula: (g citric acid / $100 \mathrm{~g}$ juice $)=(\mathrm{mL} \mathrm{NaOH} . \mathrm{N} .64 .100) /(\mathrm{g}$ sample.1000 $)$.

Experimental design: The experimental design used was entirely randomized, with 3 repetitions and 8 or 10 fruits per treatment. The means were compared using the variance analysis and Tukey test at $5 \%$ probability, using the statistical program ESTAT.

\section{RESULTS AND DISCUSSION}

\section{Essential oils in vitro activity against Colletotrichum gloeosporioides}

Table 1 shows the medicinal species studied, the oil yields and the antifungal activities (MIC $-\mathrm{mg} \mathrm{mL}^{-1}$ ). The results showed great variation amongst the yields in essential oils, between 0.001 (Allium tuberosum) and $6.7 \%$ (Cyperus articulatus). With respect to the antimicrobial activity, 15 of the 28 essential oils studied were able to inhibit $C$. gloeosporioides until $2.0 \mathrm{mg} \mathrm{mL}$. However, four medicinal species stood out, Coriandrum sativum, Cymbopogon citratus, C. flexuosus and Lippia alba, showing MIC values between 0.25 and $0.30 \mathrm{mg} \mathrm{mL}^{-1}$. These species also presented good oil yields $(0.08-1.35 \%)$.

The chemical compositions of the oils from these four species were determined by GC-MS. The compounds identified are listed in Table 2, which shows that it was possible to identify $83.57 \%$ (C. sativum) to $100 \%$ (C. citratus) of the oil constituents. The results showed the presence of volatile substances with well known antimicrobial activities, such as decenol, decanol, dodecanal and dodecanol in C. sativum, linalool, geraniol and geranil acetate in the majority of the species, and trans-cariophylene in all of the species $(18,7,17$, $8,15)$.

Based on the in vitro results, the essential oil from $C$. citratus was chosen for the tests with the yellow passion fruit, not only for its inhibitory effect but also because the cultivation parameters of this specie are well established and the oil is easy to commercialize

\section{The effect of $C$. citratus essential oil on the control of} diseases in yellow passion fruit

Table 3 shows the results for the disease index for each treatment in relation to the time employed, and Figure 1 shows the appearance of the fruits on the seventh day after treatment with $C$. citratus essential oil. The data in Table 3 show that the disease indices of the fruits submitted to treatments 3 and 4 did not differ statistically from those treated with fungicide (Sportak ${ }^{\circledR}$ - prochloraz) - (treatment 2$)$ at the $5 \%$ level of probability. At some concentrations the use of the essential oil darkened the surface of the fruit peel, at about $33.3 \%$ (treatment 3), $76.6 \%$ (treatment 4) and $100 \%$ (treatment 5), damaging their appearance and quality. Consequently, the higher essential oil concentrations resulted in higher disease indices, since the fruit peel became more susceptible to disease because of the darkening.

Table 4 shows the results of the physicochemical analyses for each treatment on the $7^{\text {th }}$ day. With respect to the changes in peel color, the fruits from day 0 (zero) and treatment 7 were more opaque than the others $\left(\mathrm{L}^{*}\right)$. In addition the fruits lost their green color and became yellow, except for those from treatments 6 and 7, which darkened due to a physiological disturbance. There were no statistical differences between the fruits with respect to soluble solids ( ${ }^{\circ}$ Brix). Finally, only the $\mathrm{pH}$ of treatment 6 was different on day 0 (zero), and only the total acidity of treatment 7 was similar to that found on day 0 (zero).

Prochloraz (imidazole fungicide) is widely used to control fungal diseases and acts by inhibiting the biosynthesis of ergosterol in the fungi. In addition in the presence of this fungicide, the mutation rate is low when compared to benzimidazoles (2). Its efficiency was previously compared with different compounds and alternative products (3) such as imazalil, thiabendazole, citric biomass, benzalconic chloride, organic and inorganic salts, Bacillus subtilis metabolites, chlorine dioxide and ozone. Prochloraz and imazalil were the 
Table 2. Compounds identified in the essential oils. IR = Retention Index; $\mathrm{Cs}=$ Coriandrum sativum; $\mathrm{Cm}=$ Cymbopogon martinii $; \mathrm{Cc}=$ Cymbopogon citratus $; \mathrm{Cf}=$ Cymbopogon flexuosus $; \mathrm{La}=$ Lippia alba .

\begin{tabular}{|c|c|c|c|c|c|c|}
\hline Compostos $^{\mathrm{a}}$ & IR & Cs & $\mathbf{C m}$ & Ce & Cf & La \\
\hline Tricicleno & 923 & & & 0,12 & & \\
\hline$\alpha$-pineno & 933 & & & 0.18 & & \\
\hline Canfeno & 948 & & & 0.94 & & \\
\hline NI & 961 & & & & 0.25 & \\
\hline octen-4-ol & 976 & & & & & 0.80 \\
\hline NI & 985 & & & 0.54 & & \\
\hline$\beta$-mirceno & 990 & & 0.12 & & & \\
\hline Octanal & 1003 & & & 0.13 & & \\
\hline dl-limoneno & 1026 & & & 0.23 & 1.53 & \\
\hline 1,8-cineol & 1028 & & & & & 2.34 \\
\hline cis- $-\tilde{\beta-o c i m e n o ~}$ & 1034 & & 0.23 & 0.21 & 0.26 & 0.26 \\
\hline 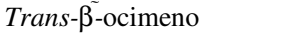 & 1044 & & 0.98 & & & 0.15 \\
\hline$M=142$ & 1071 & & & 0.42 & 0.30 & \\
\hline Linalool & 1101 & 0.27 & & 0.70 & 0.80 & 76.30 \\
\hline$M=152$ & 1144 & & & 0.49 & & \\
\hline Isopulegol & 1144 & & & & 0.47 & \\
\hline$M=152$ & 1148 & & & 0.27 & 0.23 & \\
\hline Bergamal & 1052 & & & & 0.26 & \\
\hline Citronelal & 1154 & & & 0.25 & 23.30 & \\
\hline cis-crisantemol & 1164 & & & 2.30 & 0.21 & \\
\hline$M=152$ & 1182 & & & 3.02 & 0.43 & \\
\hline$\alpha$-terpineol & 1187 & & & 0.18 & & 0.49 \\
\hline Decanal & 1205 & 5.15 & & 0.37 & 0.52 & \\
\hline Nerol & 1226 & & & 0.78 & 13.47 & \\
\hline Citronelol & 1230 & & & & & 0.81 \\
\hline Neral & 1240 & & & 35.54 & 9.64 & 0.62 \\
\hline trans-geraniol & 1254 & & 63.46 & 2.51 & 27.02 & \\
\hline ----------- & 1261 & 2.61 & & & & \\
\hline Geranial & 1269 & & & 47.52 & 12.60 & 0.83 \\
\hline 2-decen-1-ol & 1270 & 26.02 & & & & \\
\hline n-decanol & 1273 & 26.03 & & & & \\
\hline Undecanal & 1307 & 0.49 & & & & \\
\hline NI & 1331 & & & & 0.23 & \\
\hline delta-elemeno & 1336 & 0.67 & & & & \\
\hline acetato de citronelila & 1352 & & & & 0.89 & \\
\hline Eugenol & 1355 & & & 0.50 & & \\
\hline ----------- & 1369 & 1.30 & & & & \\
\hline Undecanol & 1372 & 0.85 & & & & \\
\hline acetato de geranila & 1382 & & 28.83 & 0.27 & 1.01 & 0.19 \\
\hline 放elemeno & 1387 & & & & & 0.36 \\
\hline Dodecanal & 1408 & 2.22 & & & & \\
\hline trans-cariophyleno & 1414 & 0.43 & 2.15 & 1.46 & 1.85 & 1.91 \\
\hline$\alpha$-humuleno & 1447 & & & & 0.25 & 0.26 \\
\hline -------------- & 1465 & 3.02 & & & & \\
\hline n-dodecanol & 1471 & 7.56 & & & & \\
\hline Dodecanol & 1473 & 0.95 & & & & \\
\hline M 204 & 1477 & & & & & 2.97 \\
\hline germacreno D & 1478 & & & & 0.27 & \\
\hline gama-cadineno & 1512 & & & & 1.58 & \\
\hline$\tilde{\delta}$-cadineno & 1520 & & & 0.28 & & \\
\hline Delta-cadineno & 1521 & & & & 0.32 & \\
\hline Elemol & 1546 & & & & 0.27 & \\
\hline germacreno B & 1522 & & & & & 1.91 \\
\hline n-butirato de citronelila & 1527 & & & & 0.34 & \\
\hline n-butiratode geranila & 1560 & & & & 0.34 & \\
\hline M 204 & 1562 & & & & & 0.53 \\
\hline germacreno D-4-ol & 1569 & & & & & 0.19 \\
\hline germacreno D-4-ol & 1573 & & & & 0.41 & \\
\hline óxido de cariofileno & 1579 & & & 0.81 & 0.53 & \\
\hline Tetradecanal & 1612 & 0.36 & & & & \\
\hline$\tilde{\alpha-\text { cadinol }}$ & 1651 & & & & 0.35 & \\
\hline ------------- & 1670 & 4.40 & & & & \\
\hline ------------- & 1673 & 0.85 & & & & \\
\hline (E.E) farnesol & 1720 & & 1.57 & & & \\
\hline -------- & 1776 & 0.39 & & & & \\
\hline Total & & 83.57 & 97.34 & 100.00 & 99.93 & 90.92 \\
\hline
\end{tabular}


most effective products in the control of yellow-passion fruit rots. The results from the present work show that the $C$. citratus essential oil was as efficient as Sportak® (prochloraz), with the advantage of being a natural product. In conclusion, at $0.12 \mathrm{mg} \mathrm{L}^{-1}$ and $0.25 \mathrm{mg} \mathrm{L}^{-1}$ this essential oil showed the potential for use in the control of post-harvest diseases, especially anthracnose (C. gloeosporioides), without causing physiological disturbances.

The emergence of antibiotic resistant microbial strains and the fact that the use of drugs in agriculture could contribute to the development of resistance by human pathogens have stimulated the search for natural antimicrobials. The present in vitro and in vivo results indicated the potential of $C$. citratus essential oil against $C$. gloeosporioides, the anthracnose agent in yellow passion fruit and other fruits. The fact that $C$. citratus presents a good yield in essential oil and is easily commercialized favors its use in the control of post-harvest diseases in yellow passion fruit.

Table 3. Disease indices found for the different treatments on the $2 \mathrm{nd}$, 5 th and 7 th days under environmental conditions. Results expressed in percentage (\%). Means followed by the same letter do not differ significatively according to Tukey at $5 \%$.

\begin{tabular}{llll}
\hline Treatments / days & 2nd & \multicolumn{1}{c}{ 5th } & \multicolumn{1}{c}{ 7th } \\
\hline Water (1) & $0.83 \mathrm{a}$ & $8.33 \mathrm{ab}$ & $18.33 \mathrm{~b}$ \\
Sportak ${ }^{\circledR}(2)$ & $0.00 \mathrm{a}$ & $3.33 \mathrm{bc}$ & $5.83 \mathrm{~d}$ \\
Essential oil (3) & $0.83 \mathrm{a}$ & $1.66 \mathrm{c}$ & $8.33 \mathrm{~cd}$ \\
Essential oil (4) & $0.00 \mathrm{a}$ & $6.66 \mathrm{abc}$ & $8.33 \mathrm{~cd}$ \\
Essential oil (5) & $0.00 \mathrm{a}$ & $8.33 \mathrm{ab}$ & $15.83 \mathrm{bc}$ \\
Essential oil (6) & $0.00 \mathrm{a}$ & $10.83 \mathrm{a}$ & $22.5 \mathrm{~b}$ \\
Essential oil (7) & $0.00 \mathrm{a}$ & $14.16 \mathrm{a}$ & $33.33 \mathrm{a}$ \\
\hline
\end{tabular}

Figure 1. Appearances of the passion fruits from the different treatments on the 7 th day after treatment

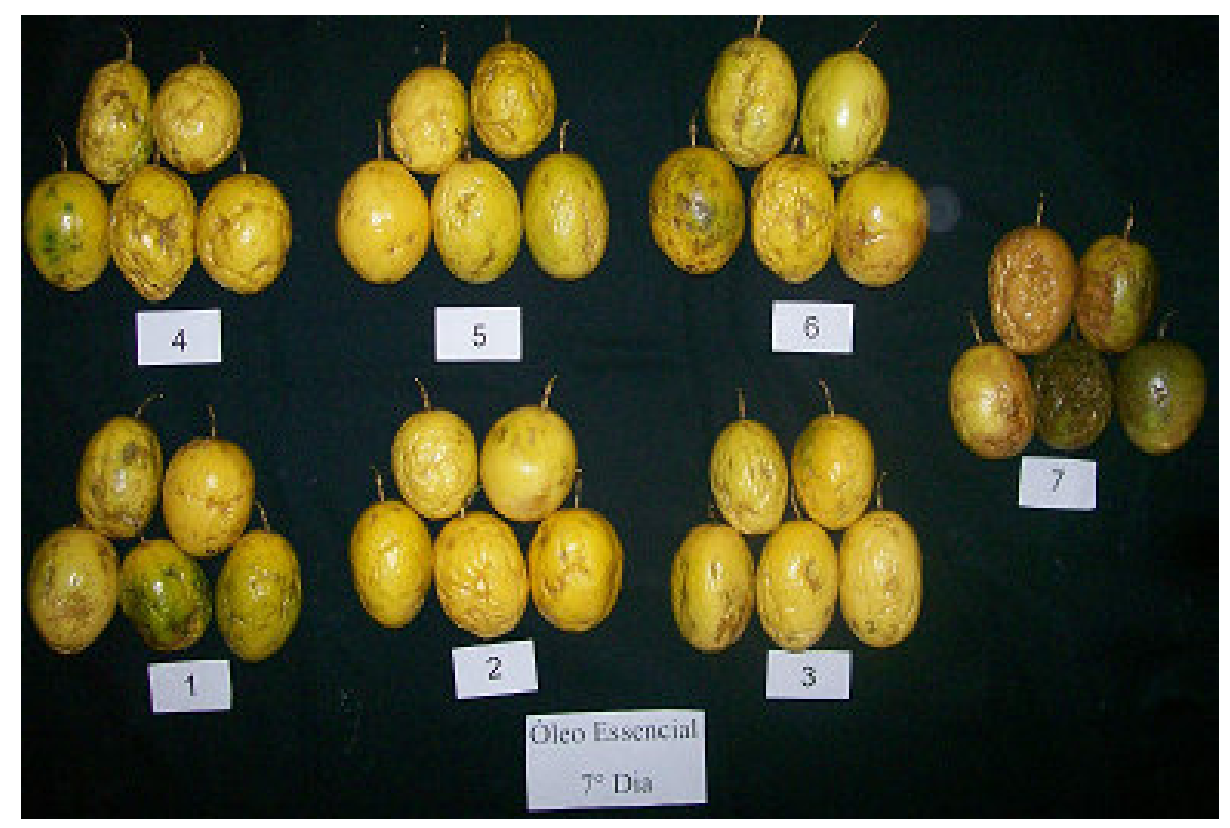


Table 4. The color $\left(\mathrm{L}^{*} \mathrm{a} \mathrm{a}^{\mathrm{b}}\right)$, soluble solids ( $\left.{ }^{\circ} \mathrm{Brix}\right), \mathrm{pH}$ and total acidity of the fruits on the 7 th day after treatment. Means followed by the same letter do not differ significantly according to Tukey at $5 \%$ in relation to the non-treated fruits

\begin{tabular}{cllllll}
\hline Treatment & \multicolumn{1}{c}{ color $\mathbf{L}^{*}$} & \multicolumn{1}{c}{ color $\mathbf{a}^{*}$} & \multicolumn{1}{c}{ color $\mathbf{b}^{*}$} & ${ }^{\circ}$ Brix & \multicolumn{1}{c}{$\mathbf{p H}$} & acidity \\
\hline $0^{* *}$ & $62.35 \mathrm{bc}$ & $-9.99 \mathrm{~b}$ & $33.42 \mathrm{bc}$ & $12.22 \mathrm{a}$ & $2.93 \mathrm{~b}$ & $4.59 \mathrm{a}$ \\
1 & $69.58 \mathrm{a}$ & $0.04 \mathrm{a}$ & $40.56 \mathrm{ab}$ & $10.47 \mathrm{a}$ & $3.06 \mathrm{ab}$ & $3.49 \mathrm{~b}$ \\
2 & $70.31 \mathrm{a}$ & $-0.65 \mathrm{a}$ & $41.85 \mathrm{a}$ & $12.75 \mathrm{a}$ & $2.97 \mathrm{ab}$ & $3.78 \mathrm{~b}$ \\
3 & $71.96 \mathrm{a}$ & $0.24 \mathrm{a}$ & $42.31 \mathrm{a}$ & $11.22 \mathrm{a}$ & $3.04 \mathrm{ab}$ & $3.54 \mathrm{~b}$ \\
4 & $70.60 \mathrm{a}$ & $0.24 \mathrm{a}$ & $41.16 \mathrm{a}$ & $12.02 \mathrm{a}$ & $3.05 \mathrm{ab}$ & $3.53 \mathrm{~b}$ \\
5 & $71.76 \mathrm{a}$ & $0.68 \mathrm{a}$ & $42.25 \mathrm{a}$ & $12.17 \mathrm{a}$ & $3.01 \mathrm{ab}$ & $3.79 \mathrm{~b}$ \\
6 & $66.49 \mathrm{ab}$ & $-1.15 \mathrm{a}$ & $36.92 \mathrm{ab}$ & $11.35 \mathrm{a}$ & $3.11 \mathrm{a}$ & $3.32 \mathrm{~b}$ \\
7 & $57.74 \mathrm{c}$ & $2.49 \mathrm{a}$ & $26.28 \mathrm{c}$ & $10.72 \mathrm{a}$ & $3.06 \mathrm{ab}$ & $3.85 \mathrm{ab}$ \\
\hline **Day zero - non-treated & & & & &
\end{tabular}

\section{ACKNOWLEDGMENTS}

The first author is grateful to CNPq for the scholarship.

\section{REFERENCES}

1. Adams, R.P. (2007). Identification of Essential Oil Components by Gas Chromatography/ Mass Sppectrometry. Allured Publ. Corp.,Carol Stream, IL.

2. Barkay-golan, R. (2001). Postharvest diseases of fruits and vegetables: development and control. Amsterdam: Elsevier, 417pp.

3. Benato, E.A.; Sigrist, J.M.; Hanashiro, M.M.; Magalhães, M.J.M.; Binotti, C.S. (2002). Avaliação de fungicidas e produtos alternativos no controle de podridões pós-colheita em maracujá-amarelo. Summa Phytopathologica 28, 299-304.

4. Binotti, C.S.; Benato, E.A.; Sigrist, J.M.M.; Berthier, LJ, Calegario, F.F.; Carina, T.; Moreira, T. (2002). Efeito da radiação ultravioleta (UV-C) no controle de podridões pós-colheita de maracujá-amarelo. In: Livro de Resumos da Reunião Técnica de Pesquisa em Maracujazeiro, Viçosa, UFV 3.

5. Cowan, M.M. (1999) Plant products as antimicrobial agents. Clin. Microbiol. Rev. 2, 564-582.

6. Curtis, H.; Noll, U.; Störmann, J.; Slusarenko, A.J. (2004). Broadspectrum activity of the volatile phytoanticipin allicin in extracts if garlic (Allium sativum L.) against plant pathogenic bacteria, fungi and Oomycetes. Physiol. Mol. Plant Phathology 65, 79-89.

7. Cruz, T.; Cabo, M.M.; Castillo, M.J.; Jimenez, J.; Ruiz, C. (1993). Chemical composition and antimicrobial activity of the essential oils of different samples of Thymus baeticus Boiss. Phytother Res., 7, 92-94.

8. Douglas, M.H.; van Klink, J.W.; Smallfield, B.M.; Perry, N.B.; Anderson, R.E.; Johnstone, P. (2004). Essential oils from New Zealand manuka: triketone and other chemotypes of Leptospermum scoparium. Phytochemistry 65, 1255-1264.
9. Garruti D.S. (1989). Contribuição ao estudo da estabilização física do suco de maracujá integral (Passiflora edulis F. flavicarpa Deg.). Dissertação de Mestrado, Tecnologia de alimentos - Faculdade de Engenharia de Alimentos, Unicamp.

10. Goodman, R.N. (1959). The influence of antibiotics on plants and plant disease control. In: Antibiotics: Their Chemistry and Non-Medical Uses, ed. HS Goldberg, 322-448.

11. Iacobells, N.S.; Cantore, P.; Capasso, F.; Senatore, F. (2005). Antibacterial activity of Cuminum cyminum and Carum carvi L. Essential Oils. J. Agric. Food Chem. 53, 57-61.

12. Leiter, É.; Marx, F.; Pusztahelui, T.; Haas, H.; Pócsi, I. (2004) Penicillium chrysogenum glucose oxidase - a study on its antifungal effects. J. Appl. Microbiol. 97, 1201-1209.

13. Maruzzella, J.C.; Reine, S.; Solat, H.; Zeitlin, H. (1963). The action of essential oil son phytopathogenic bacteria. Plant Dis. Rep. 47, 23-26.

14. Mcmanus, P.S.; Stockwell, V.O.; Sundin, G.W.; Jones, A.L. (2002). Antibiotic use in plant agriculture. Ann. Rev. Phytopatol. 40, 443-65.

15. Mimica-Dukic, N.; Bozin, B.; Sokovic, M.; Simin, N. (2004). Antimicrobial and antioxidant activities of Melissa officinalis L. (Lamiaceae) essential oil. J. Agric. Food Chem. 52, 2485-2489.

16. NCCLS. (2002). Método de referência para testes de diluição em caldo para a determinação da sensibilidade a terapia antifúngica dos fungos filamentosos: Norma Aprovada, M38-A, 22: 50pp.

17. Pattnaik, S.; Subramanyam, V.R.; Bapaji, M.; Kole, C.R. (1997). Antibacterial and antifungal activity of aromatic constituents of essential oils. Microbios 89, 39-46.

18. Scortichini, M.; Rossi, M.P. (1991). Preliminary in vitro evaluation of the antimicrobial activity of terpenes and terpenoids towards Erwinia amylovora. 263

J. Appl. Bacteriol. 71, 109-112.

19. Snowdon, A.L.A. (1990). A colour atlas of post-harvest diseases \& disorders of fruits \& vegetables: general introduction \& fruits. London: Wolfe Scientific, 302pp. 